\title{
Attacking the mainline
}

\section{Munich}

THANKs to a US crackdown on the export of chemicals that could be used in the preparation of illegal drugs, European chemical companies may be attracting some new but unwelcome business. With prompting from West Germany, which already feels guilty over scandals surrounding the export of materials for the production of chemical weapons, officials of the European Commission are now considering concerted action to control the export of drug precursors, and chemicals which include solvents like acetone. Such action could "hand a major defeat to the drug producers", according to Gene Haislip, an official at the US Drug Enforcement Administration (DEA). Illegal drug producers require regular shipments of large quantities of the substances, all of which are so-called 'dual-use' chemicals required for the production of legal substances as well as of cocaine, amphetamines and other illegal drugs (see table). West Germany will be the first European country to take action, with a strict export law to restrict access to 12 substances expected to be introduced into parliament during next year. The law would require that export licences be granted by the government before any of these chemicals can be shipped.

Until now, it has been impossible to prosecute brokers who have bought the substances from unwitting producers and sold them to illegal drug producers in Colombia. The brokers "definitely" include German nationals, among others, says Haislip. But other chemical producers in Europe oppose introduction in the European Communities (EC) of the West German licensing system because they feel it would be ineffective. "It is just too easy to circumvent the licensing requirement by falsifying documents", says an official for the EC customs directorate in Brussels, "we only have the staff to check

one per cent of the exports". The opponents of licensing, who are thought to include France, Britain and the Netherlands, would prefer a system of registration of exports with the authorities, who would then investigate suspicious cases. But Haislip thinks this system would not be as efficient as a licensing system, which has already been shown to work with other drugs. Haislip says that the United States and Europe, working together, managed to stop the export of the chemical methaqualone, a precursor for the tranquillizers known as quaaludes. The export of quaaludes from Colombia to the US then fell by 99 per cent. "We cut off their water and they never could find the faucet", boasts Haislip.

Haislip also favours careful scrutiny of the buyers of the chemicals. DEA cut off US shipments of the chemicals to a remarkable 70 per cent of buyers in Colombia after determining that they were channelling the chemicals to illegal drug laboratories.

The proposed West German law is opposed by the chemical industry in West Germany, which does not want to be singled out for cumbersome export-licensing unless its European competitors are similarly burdened. Manfred Ritz, a spokesman for the industry association Verband der Chemischen Industrie in Frankfurt, says that the current system of voluntary controls is perfectly adequate and has even achieved some spectacular successes.

If experience with chemical weapons plant exports is any indication, the progress of the proposal into West German law, let alone European law, will be very slow. Proposed strict export laws meant to prevent a repetition of the debacle in Libya have become bogged down in the West German parliament, which will be hard pressed to pass them by the end of the year.

Steven Dickman

ILLEGAL DRUG PRECURSORS AND SOLVENTS

Compound

(1) Ephedrine

(2) Ergometrine

(3) Ergotamine

(4) Lysergic acid

(5) 1-Phenyl-2-propanone

(6) Pseudophedrine

(7) Acetic anhydride

(8) Acetone

(9) Anthranilic acid

(10) Ethyl ether

(11) Phenylacetic acid

(12) Piperidine

$\begin{array}{ll}\text { Illegal use } & \text { Legal use } \\ \text { Amphetamine } & \text { Bronchial dilator } \\ \text { Amphetamine } & \text { Blood pressure, migraine medication } \\ \text { Amphetamine } & \text { Blood pressure, migraine medication } \\ \text { Amphetamine, LSD } & \text { Precursor for 2, 3 } \\ \text { precursor } & \\ \text { Amphetamine precursor } & \text { Amphetamine precursor } \\ \text { Amphetamine precursor } & \text { Bronchial dilator } \\ \text { Heroin synthesis } & \text { Common solvent; sulphonamide, } \\ & \text { vitamin B6 and aspirin synthesis } \\ \text { Cocaine synthesis } & \text { Common solvent; indigo and } \\ & \text { perfume synthesis } \\ \text { Designer drug synthesis } & \text { Indigo and perfume synthesis } \\ \text { Cocaine synthesis } & \text { Acetylating agent, dyestuff } \\ & \text { synthesis } \\ \text { Designer drug synthesis } & \text { Penicillin, dyes and perfume } \\ & \text { synthesis } \\ \text { Designer drug synthesis } & \text { Drugs, pesticides, perfume } \\ & \text { synthesis; hardens resins }\end{array}$

Export of these 12 substances from Europe is to be restricted. The 1989 Vienna Protocol recommended stricter controls on all 12 substances and their salts.

\section{Going by the Board}

\section{San Francisco}

DESPITE significant faculty opposition, the University of California (UC) Board of Regents voted on 21 September to renew for another five-year term the university's contract to manage the Los Alamos and Lawrence Livermore National Laboratories, home to much US nuclear weapons research.

UC receives about $\$ 12$ million a year from the contracts with the Department of Energy (DOE) to cover the expenses of managing the Livermore and Los Alamos laboratories, as well as the Lawrence Berkeley Laboratory, which conducts non-classified scientific research.

The vote, 13 to 3 with one abstention, was to open negotiations with the DOE for a new five-year contract which will begin in September 1992.

Many members of the UC faculty opposed the decision to continue the management contract because they believe that the link to weapons development and testing is fundamentally inappropriate for a public academic institution. In a vote taken last spring on eight of the nine UC campuses, 64 per cent of the faculty felt the university should phase out its operation of Livermore and Los Alamos, while "maintaining its current cooperative relationship with the laboratories in teaching and research".

But UC president David P. Gardner last week urged the regents to continue the 47-year relationship with the laboratories, saying that it would be "particularly ironic" to relinquish the management responsibilities now, when the world situation is changing so dramatically.

Livermore is also anxious to maintain its connection with the university. Robert Borchers, chairman of Livermore's University Relations Committee, sees the negative attitude of the faculty as something "rooted in the past". He believes that the shifting focus of the laboratories' research, including a decrease in the amount of classified research being done (classified projects now constitute only 25 per cent of the Livermore's work), can only improve relations with the university and may lead to more academic collaborations.

Beyond the philosophical disagreements, some critics have argued that the university's management has been inadequate, allowing drug abuse, security and environmental problems to crop up. Responding to those concerns, Gardner claims he is developing specific recommendations for improving management procedures.

Elizabeth Schaefer 